\title{
Impact from Productivity and State-ownership of Chinese Agricultural Firms on ODI Decisions
}

\author{
Naixi Liu \\ Department of International Economics, China Foreign Affairs University, Beijing, China \\ Email address: \\ liunaixi@cfau.edu.cn

\section{To cite this article:} \\ Naixi Liu. Impact from Productivity and State-ownership of Chinese Agricultural Firms on ODI Decisions. International Journal of \\ Agricultural Economics. Vol. 5, No. 1, 2020, pp. 18-29. doi: 10.11648/j.ijae.20200501.13
}

Received: January 8, 2020; Accepted: January 31, 2020; Published: February 11, 2020

\begin{abstract}
Chinese agricultural outward direct investment has grown rapidly over the last decades. Neo-classical foreign direct investment theories can explain the reasons in motivation perspective reasons for the rapid growth, but cannot explain what types of agricultural firms would be most likely to undertake outward direct investment to together make the rapid growth. We use a Chinese agricultural firm level dataset matched from Chinese industrial enterprises database and Chinese outward direct investment enterprises database to empirically examine the relationship between firm heterogeneity and outward direct investment decisions. We find the estimation results support the Helpman-Melitz-Yeaple hypothesis that as the first firm heterogeneity the total factor productivity has a positive influence on the probability that a firm will undertake outward direct investment, which is in accordance with the past related research especially the recent theoretical research progress of international direct investment. In contrast, we find that as the second firm heterogeneity the state ownership has a negative influence on the probability that a firm will undertake outward direct investment, which is not in accordance with the past research on Chinese overall outward direct investment and could be explained by the domestic support obligations of the state-owned agricultural firms in China. Furthermore, we implement robust estimation and the results shows a significant robustness. Our research shows that firm heterogeneity dose matter and it is important to take this into account in analyzing Chinese agricultural firms' outward direct investment decisions.
\end{abstract}

Keywords: China, Productivity, Outward Direct Investment, State Ownership

\section{Introduction}

Chinese agricultural outward direct investment (ODI) ${ }^{1}$ has grown rapidly over the last decade. Neo-classical foreign direct investment theories can explain the reason for rapid growth, but cannot explain what types of entities would be most likely to undertake ODI.

Recent theoretical research on outward direct investment has tried to incorporate diverse modes of foreign market access into trade theory by explaining ODI choices in terms of firm heterogeneity. In an empirical study, Helpman, Melitz and Yeaplefound that total factor productivity (TFP) could answer the "which companies" question [1], in that companies with high TFP will choose to engage in ODI. Some research

1 Also as called outward foreign direct investment (OFDI) in some other literatures; the word ODI or OFDI referenced in this paper has exactly the same meaning. has suggested that state ownership could also influence the ODI choices of Chinese firms [2, 3].

In this paper, we examine the relationship between ODI behavior, and TFP and state ownership, to determine whether these two factors influence ODI choices by Chinese agricultural firms. Following Tian and Yu's research [4], we estimate two logit equations using firm level data. The dataset is constructed by matching industrial enterprises data for 1998 to 2009, compiled by the National Bureau of Statistics. and outward direct investment enterprises' name list data published by the Ministry of Commerce in 2015.

We find that TFP enhances the probability that Chinese agricultural firms will choose to engage in ODI, which supports the HMY hypothesis [1]. We also find that state ownership reduces the probability that firms will choose to engage in ODI. We offer some suggestions as to why this may be case. Our results support the view that firm heterogeneity matters for cross-border behavior, and that private agricultural 
companies are likely to play a significant role in Chinese agricultural ODI.

\section{Background and Literature Review}

Chinese agricultural ODI has grown rapidly over the last decade. The annual outflow was just 0.27 billion US dollars (USD) in 2007 but increased to 2.57 billion USD in 2015. The stock of ODI increased from 1.47 billion USD to 11.4 billion $\mathrm{USD}^{2}$ over the same period, or almost tenfold.

A number of factors have been identified that could explain the transformation from a domestic to a cross-border industry [5]. These include tariff and non-tariff barriers [6], internalization advantages [7], monopoly competition advantages [6-8], and the industry life cycle [7, 9]. Dunning argues that from a firm's perspective the motivation for ODI could be market development, limited domestic natural resources [10], cost saving and profit promoting advantages, and access to strategic assets, such as technology especially for the Chinese firms [11]. These four motivations may apply to Chinese agricultural ODI, but it is difficult to use them to examine empirically which companies will choose to focus on foreign investment.

\subsection{TFP and ODI}

Recent research on ODI has tried to incorporate diverse modes of foreign market access into new trade theory by explaining investment choices in terms of firm heterogeneity. Melitz reported that only the most productive firms engage in foreign activities [12]. Helpman, Melitz and Yeaple [7] ${ }^{3}$ developed this idea further to posit that only the most productive firms engage in ODI, the second most productive engage in export and the least productive engage in serving domestic markets. Since that work, many empirical papers have tested this hypothesis. Several of these are summarized in Table 1. We can see that a substantial amount of research supports the HMY hypothesis on which companies choose to pursue ODI.

\subsection{State Ownership and $\mathrm{ODI}$}

China has a large number of state owned companies, and this applies in the agricultural field. Some research suggests that state ownership could be an important element in explaining the cross-border behavior of Chinese enterprises $[3$ 10, 11, 31-33]. Two potential aspects of the impact of state ownership have been identified. First, it could enhance financial capability and credit availability so that state-owned firms are able to access finance at lower cost and to undertake greater investment risk than private firms [2, 3, 34]. This may

2 Data Source: National Bureau of Statistics of China. flow data: data.stats.gov.cn/easyquery.htm?cn=C01\&zb=A060G01; stock data: data.stats.gov.cn/easyquery.htm? $\mathrm{cn}=\mathrm{C} 01 \& \mathrm{zb}=\mathrm{A} 060 \mathrm{G} 02$.

3 The theoretical framework was based on the proximity-concentration tradeoff [23]. The empirical test only included a sample involving horizontal integration [24 25]; without observations involving vertical integration [26, 27]. The limitation that theoretically the HMY hypothesis [7] does not apply to every ODI case has been pointed out by Engel and Procher's work [28] lead to a higher probability of profitability from cross border investments by state owned companies. Second, state owned companies may have to make some investment decisions for political or diplomatic reasons, rather than simply for business reasons. These motivations may also prompt host countries to erect barriers to protect domestic industries and to restrict foreign investment [3].

\subsection{Implications}

On the basis of the discussion above we can conclude that both TFP and state ownership could be important elements for ODI choices by Chinese agricultural enterprises. A reasonable hypothesis would be that Chinese agricultural enterprises with high TFP or under state ownership would be more likely to undertake ODI than those with lower TFP or without state ownership. In this paper, we test this hypothesis empirically based on firm level data.

\section{Data Illustration}

To conduct the analysis we merge two sources together into one panel dataset via cleaning and matching.

The first source is the Chinese industrial enterprises database (CIED), which is an annual survey of all Chinese industrial enterprises above a minimum size conducted by the National Bureau of Statistics from 1998 to $2009^{4}$. This includes all the companies' basic information including name, start year, address, industry sector etc., and annual financial information. Only companies with sales of at least 5 million CNY (about 0.72 million USD), are included in the annual survey. In our analysis we only consider those companies that have undertaken ODI, and exclude those that have not.

The second data source is the Chinese outward direct investment enterprises' name list (CODIENL) published annually by the Ministry of Commerce. This includes the company's registration number, domestic name, enterprise name in the host country, host country, industry category, and years for which ODI was undertaken. We use the list published in December 2015, which covers all the companies that invested outside China from 1983 to $2015^{5}$.

\subsection{CIED Data}

From the CIED database, we selected all the companies related to agriculture based on their industry code. The names are listed in appendix A1. Using the similar data cleaning method in Dai, Maitra and Yu's framework [35], we dropped the observations in which there was a missing or negative value for any of following variables: total sales, total employment, fixed capital, current assets, and state ownership.

After data cleaning, the effective sample size by year is

4 Actually, there are some CIED data until the year of 2012, but questions have been raised about the quality of some of the data. In this paper, we only use the data up to 2009.

5 The data can be accessed at:

http://femhzs.mofcom.gov.cn/fecpmvc/pages/fem/CorpJWList.html. 
shown in figure 1 . We have 313,203 observations in total, or about $88 \%$ of the original 354,678 observations. From figure 1 we can see that sample size was at a maximum of 57,881 in 2009 and at a minimum of 5,748 in 2001 . We can also see that the number of Chinese agricultural companies with ODI tended to decline in the first five years of the sample period, but expanded rapidly thereafter.
The ownership status of the observations is summarized in figure 2. Given the situation in China, firms that fall under the national holding and local state holding categories can be considered to be under state ownership. All other types (including private holding, Hong Kong Macau and Taiwan holding, foreign holding and other holding) can be considered as being under private ownership.

Table 1. Some empirical tests of the HMY hypothesis in recent years.

\begin{tabular}{|c|c|c|c|c|c|}
\hline Literature & Sample Country & Sample Period & Samples Industry & Empirical Method & $\begin{array}{l}\text { HMY Hypothesis: } \\
\text { Yes or No? }\end{array}$ \\
\hline Girma et al. [13] & UK & $1990-1996$ & Manufacturing & Nonparametric KS Test ${ }^{6}$ & Yes \\
\hline Murakami [14] & Japan & 1998 & Manufacturing & $\mathrm{OLE}^{7}$ & Yes \\
\hline Wagner [15] & German & 1995 & Manufacturing & Nonparametric KS Test & Yes \\
\hline Kimura and Kiyota [16] & Japan & $1994-2000$ & $\begin{array}{l}\text { Manufacturing and } \\
\text { Service Industry }\end{array}$ & OLE & Yes \\
\hline Castellani and Zanfei [17] & Italia & 1994-1996 & Manufacturing & Nonparametric KS Test & Yes \\
\hline Yeaple (2009) [18] & USA & 1994 & Manufacturing & OLE & Yes \\
\hline Chen and Moore [19] & France & $1993-2001$ & Manufacturing & OLE & Yes \\
\hline Arnold and Hussinger [20] & German & $1996-2002$ & Manufacturing & Nonparametric KS Test & Yes \\
\hline Todo [21] & Japan & $1997-2005$ & Manufacturing & OLE & No \\
\hline Hagemejer and Kolasa [22] & Poland & $1996-2005$ & All industries & Nonparametric KS Test & Yes \\
\hline Tian and $\mathrm{Yu}[4]$ & China & 2006-2008 & All industries & OLE (Fixed effect) & Yes \\
\hline Engel and Procher [28] & France & 2004 & $\begin{array}{l}\text { All industries except } \\
\text { agriculture }\end{array}$ & Nonparametric KS Test & Yes \\
\hline Tanaka [29] & Japan & $1997-2009$ & Retailing & OLE & Yes \\
\hline Shepherd [30] & 119 Developing Countries & 2006-2011 & Service Industry & OLE & Yes \\
\hline
\end{tabular}

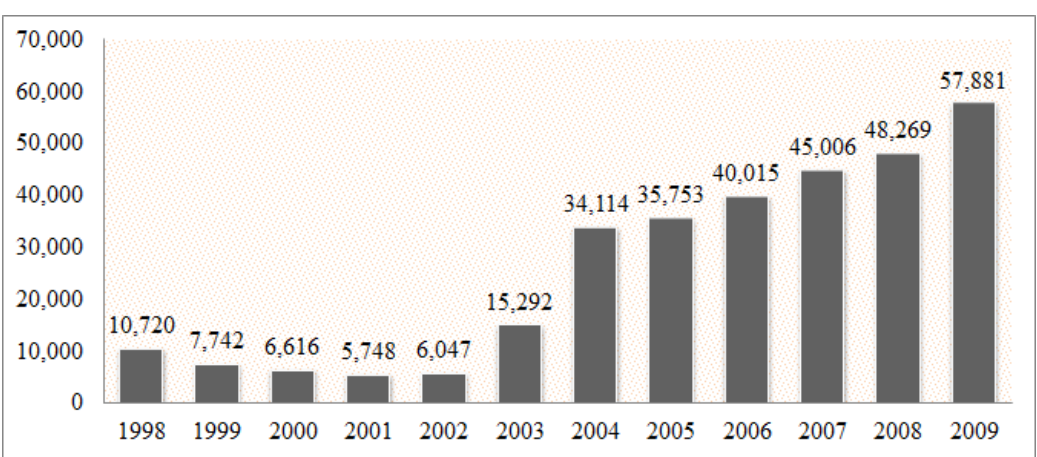

Source: CIED Database.

Figure 1. Annual Chinese Agricultural Firms Sample 1998-2009.

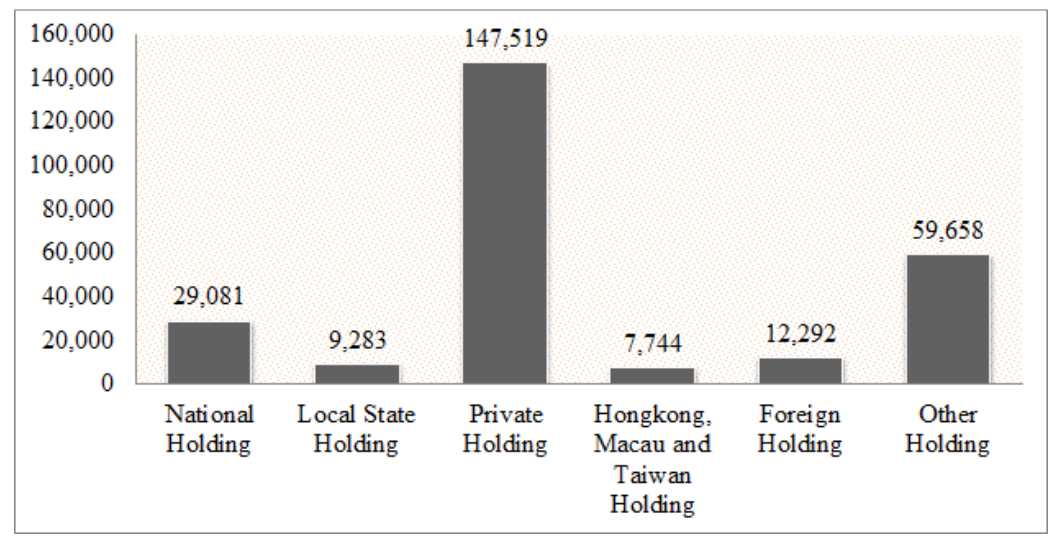

Source: CIED Database.

Figure 2. Ownership Status of the Agricultural Firms Sample 1998-2009.

6 The nonparametric KS test in this paper means the Kolmogorov-Smirnov test, which is based on the concept of stochastic dominance.

7 Ordinary Linear Estimation. 


\subsection{CODIENL Data}

In order to test our hypothesis at the firm level, we have to know which agricultural companies have invested outside China. On the basis of the CODIENL data published in December 2015, we delete the observations with no company name information and finally we have 41,713 observations on Chinese companies that have undertaken ODI, of which 3,587 are agriculture related.

\subsection{Data Matching and Merging}

After cleaning the CIED data we have observations on Chinese agricultural companies above the minimum scale identified earlier, and their financial performance during the period 1998 to 2009. From the CODIENL after-cleaning dataset, we have the names of 3,587 Chinese agricultural companies that have undertaken ODI. In a matching and merging process, we combined the CIED and CODIENL data into a single dataset. We also generate the dependent variable "ODI" to define whether a company has undertaken ODI or not.

With data matching, we have 529 Chinese agricultural companies, which are reported to have undertaken ODI from the CODIENL data that are also found in the CIED data. This implies that during the sample period roughly $15 \%$ of Chinese agricultural companies which have invested outside China are above scale firms. This implies that many Chinese agricultural companies which have invested outside China are small or medium enterprises.

The variable ODI takes on a value of 1 when a company's name is included in both the CIED and CODIENL data, and that the company is recorded as having undertaken ODI in a given year. The value of 0 applies when these conditions are not met. For example, suppose there are three companies A, B and $\mathrm{C}$ which can be found in both CIED and CODIENL data. If company A has undertaken ODI in all years since 1998, then the value of the ODI variables for the 12 observations will be 1 . If company B has not undertaken ODI since 1998 its 12 observations will have a value of 0 . If company $\mathrm{C}$ has undertaken ODI since 2003 the value of the ODI variable for the first five observations from 1998 to 2002 will be 0 and those for the seven observations from 2003 to 2009 will be 1 .

\section{Empirical Methods}

\subsection{Empirical Equations}

As shown in Table 1, many researchers have used a fixed effect model to test the HMY hypothesis. For example, Tian and $\mathrm{Yu}$ [4] used this approach on firm level data for all industries in China from 2006 to 2008. Following that approach we construct two logit ${ }^{8}$ equations as follows:

First, by considering the data as panel data:

8 Compared to using probit estimation, logit estimation can be more stable and avoid non-consistency when involving fixed effects [36].

$$
\begin{gathered}
\operatorname{Pr}\left(O D I_{\mathrm{it}}=1 \mid X_{i t}\right)=\beta_{0}+\beta_{1} \ln ^{T F P}+\beta_{2} \text { Ownership }+ \\
\beta_{3} F R G+\beta_{4} A g e_{i t}+\varepsilon_{i t}
\end{gathered}
$$

Second, by considering the data as pooled cross-sectional data:

$$
\begin{gathered}
\operatorname{Pr}\left(O D I_{\text {it }}=1 \mid X_{i t}\right)=i d_{i}+\text { year }_{t}+\beta_{0}+\beta_{1} \ln ^{T F P}+ \\
\beta_{2} \text { Ownership }+\beta_{3} F R G+\beta_{4} \text { Age } e_{i t}+v_{i t}
\end{gathered}
$$

Fixed effect logit estimation is efficient when the within group variance of the dependent variable is non zero, but in our data there are many companies that have never invested outside China. Consequently, the within group variance of the variable ODI could be 0 for many observations. This would require the deletion of a large number of observations. To deal with this problem we use both fixed and random effect logit estimation by treating the data as panel data. This allows us to control directly the company id and year variables. A priori we cannot know whether a fixed or random effects model is more suitable, so we use the Likelihood Ratio and Hausman tests to determine this.

\subsection{The Variables}

In the equations, $\mathrm{X}$ denotes the sample companies, $\mathrm{i}$ is the index for each sample company, $t$ is the sample year. The variable $O D I$ has a value of 1 if the company undertook ODI otherwise the value is 0 .

The variable "id" is the unique identification code for each company. It has no actual numerical meaning but is used here to control for fixed effects among diverse companies. Some uncommon elements may influence a company's ODI decision but it is hard to obtain information or precise data to reflect these. These elements can include such things as the foreign language capability of the company's managers or non-business preferences.

The variable "year" is used to control for fixed effects across different years, for example, differences in domestic or international macroeconomic conditions. For example, the global financial crisis of 2007-08 may have influenced the investment behavior of companies, leading some to suspend plans for cross-border activity.

The variable "TFP" denotes a company's Total Factor Productivity, calculated using the OP method [35, 37, 38]. Two major considerations underlie the choice of this method (see appendix A2). First, other methods for calculating TFP based on micro data (e.g., the classical OLS method) tend to be less efficient. Second, most recent research based on CIED data has found OP to be more effective and stable than alternatives. $\mathrm{Lu}$ and Lian examined several methods and concluded that the OP method generated the most plausible and stable estimates of TFP from CIED data [39].

The variable "Ownership" is a dummy variable that is equal to 1 if a firm is state owned and 0 otherwise. The variable "FRG" is a dummy variable with a value of 1 if the company itself has received foreign investment. If a company has been the target of FDI it is likely to be more open to international 
activity. Companies that have received foreign capital may have greater access to international business contacts, information, and expertise if they want to go outward. The variable "Age" reflects the age of the company (number of years that it has been operating). The longevity of the company and the experience of its management people may influence investment behavior, e.g., through attitudes to risk.

\section{Result and Discussion}

\subsection{Estimation Result}

After estimation we obtain the results in Table 2. The Likelihood Ratio and Hausman test results are summarized in Table 3.

\subsection{Discussion}

On the basis of Tables 2 and 3, we note the following major characteristics:

From Table 3, we can see that both the LR and Hausman tests suggests that random effect logit estimation is more suitable for our case when viewing the data as panel data. Also from the effective sample amount "N" in Table 2, we can see that the application of the condition that the within group variance of the dependent variable should not be zero results in a substantial reduction in sample size. Thus the fixed effect logit estimation based on panel data is not suitable for our case.

From Table 2, we can see that in both the random effect logit panel estimation and the pooled logit estimation, the coefficients for TFP are strongly positive. This suggests that TFP matters for Chinese agricultural firms' ODI choices; companies with higher TFP have a higher probability of engaging in ODI. This provides support for the HMY hypothesis in Chinese agricultural firms.

\begin{tabular}{llll}
\hline & (1-Fixed Effect Panel Logit) & (2-Random Effect Panel Logit) & (3-Pooled Logit) \\
\cline { 2 - 4 } & ODI & ODI & ODI \\
\hline TFP & $2.050^{* * *}$ & $1.921^{* * *}$ & $1.316^{* * *}$ \\
& $(3.56)$ & $(9.78)$ & $(21.85)$ \\
Ownership & 0.968 & $-0.661^{*}$ & $-0.825^{* * *}$ \\
& $(1.61)$ & $(-2.37)$ & $(-4.78)$ \\
FRG & $1.754^{*}$ & $1.068^{* * *}$ & -0.152 \\
& $(2.55)$ & $(4.36)$ & $(-1.16)$ \\
Age & $0.639^{* * *}$ & 0.00343 & -0.000948 \\
& $(10.39)$ & $(1.06)$ & $(-0.21)$ \\
id & & & $-0.00000846^{* * *}$ \\
& & & $(-5.34)$ \\
year & & & $0.470^{* * *}$ \\
& & & $(16.33)$ \\
constant & & $-25.05^{* * *}$ & $-954.3^{* * *}$ \\
& & $(-26.06)$ & $(-16.52)$ \\
$N$ & 907 & 310107 & 310107 \\
\hline
\end{tabular}

$t$ statistics in parentheses; ${ }^{*} p<0.05,{ }^{* *} p<0.01,{ }^{* * *} p<0.001$.

Table 3. Likelihood Ratio and Hausman Test Results.

\begin{tabular}{lll}
\hline & Chibar2 & P-value \\
\hline LR Test & $59609.79^{* * *}$ & 0.000 \\
Hausman Test & $3169.37^{* * *}$ & 0.000 \\
\hline
\end{tabular}
${ }^{*} p<0.05,{ }^{* *} p<0.01,{ }^{* * *} p<0.001$.

Table 4. Robust IV Estimation Results.

\begin{tabular}{lll}
\hline & (2 - Random Effect Panel Logit) & (3 - Pooled Logit) \\
\cline { 2 - 3 } & ODI & ODI \\
\hline L_tfp & $2.029^{* * *}$ & $1.353^{* * *}$ \\
& $(9.57)$ & $(20.02)$ \\
ownership & $-0.650^{*}$ & $-0.922^{* * *}$ \\
& $(-1.96)$ & $(-4.71)$ \\
frg & $0.861^{* *}$ & -0.143 \\
& $(3.08)$ & $(-1.01)$ \\
\hline
\end{tabular}




\begin{tabular}{lll}
\hline & (2 - Random Effect Panel Logit) & (3 - Pooled Logit) \\
\cline { 2 - 3 } & ODI & ODI \\
\hline age & 0.00101 & -0.00413 \\
& $(0.17)$ & $(-0.81)$ \\
id & & $-0.00000761^{* * *}$ \\
& & $(-4.02)$ \\
year & & $0.415^{* * *}$ \\
& & $(12.86)$ \\
Constant & $-28.17^{* * *}$ & $-845.3^{* * *}$ \\
& $(-28.16)$ & $(-13.03)$ \\
$N$ & 202462 & 202462 \\
\hline
\end{tabular}

$t$ statistics in parentheses ${ }^{*} p<0.05,{ }^{* *} p<0.01,{ }^{* * *} p<0.001$.

Also from Table 2, we can see that in both random effect logit panel estimation and pooled logit estimation, the coefficients of ownership are negative and statistically significant, which suggests that state-ownership matters for Chinese agricultural firms but with the opposite effect from that found in past research (Cui and Jiang, 2012). Our results suggest that if an agricultural company is state-owned, it will have a smaller probability of engaging in ODI. The reason for this may involve two aspects. First, Chinese state owned agricultural firms are required to take on significant financial obligations to support domestic agricultural development. Many have to incur deficits to engage in market intervention through schemes such as the "minimum purchase prices policy" and "temporary purchases and storage policy" which require state owned companies to purchase domestic grain production at prices higher than for imported grain. This financial commitment may limit the ability of state owned companies to expand their domestic business, let alone invest abroad. Second, in recent years, Chinese state owned agricultural companies may have had to face restrictions and barriers to investing abroad as a result of political constraints in host countries. In our sample, only 87 state owned companies have undertaken ODI or $8 \%$ the total of 1089 companies which undertook ODI in 1998 - 2009.

\subsection{Robust Estimation}

The estimates obtained lend support to the hypothesis stated earlier about the relationship between TFP and state ownership for ODI by Chinese agricultural firms. However, there could be endogeneity in the estimation. Companies which undertake ODI may experience spillover benefits, also called a learning effect by some researchers [39]. For example, a processing company that has invested overseas to build a new plant, may learn from that experience in terms of optimizing the use of its technology, and the application of that experience domestically can induce gains in TFP.

To deal with this possibility, we use the TFP from previous year (L_tfp) as an instrumental variable (IV) of TFP. The estimation results are reported in Table 4.

The results in Table 4 suggest that even allowing for endogeneity in TFP, the results in Table 3 are still supported. Consequently, we can conclude that we have a robust outcome from the application of our empirical framework.

\section{Conclusions and Implications}

Our empirical study used Chinese agricultural firm level data to study the relationship between outward direct investment behavior, focusing on total factor productivity and state ownership. Through logit estimation we find support for the HMY hypothesis [7], that is agricultural firms with higher TFP are more likely to have invested overseas. We also find that companies that have attracted foreign capital are more likely to have engaged in outward direct investment than those which have purely domestic capital in their financial structure.

We also found that agricultural firms under state ownership are less likely to engage in outward direct investment. This is counter to results obtained for other sectors. There are two potential reasons. First, state owned firms in the agricultural sector are expected to contribute to the development of agriculture through various types of expenditure, potentially leaving them with limited funds to allocate to ODI. Second, sensitivity to foreign investment in agriculture in host countries may make it difficult for state owned agricultural companies' to engage in cross-border investment. Further research would be needed to explore the factors that underlie ODI behavior of state-owned firms across different industries. This could be important for determining the future role of state-owned versus privately-owned firms in Chinese ODI and for understanding how China will participate in globalization. Finally, while our results lend support to the HMY hypothesis, they also indicate that firm heterogeneity can play a major role in cross-border investment behavior, and that it is important to take this into account.

9 Information about these two policies is contained in a report about grain and feed in China by the US Department of Agriculture: http://gain.fas.usda.gov/Recent\%20GAIN\%20Publications/Grain\%20and\%20Fee d\%20Annual_Beijing_China\%20-\%20Peoples\%20Republic\%20of_5-11-2015.pd 


\section{Appendix}

Appendix 1 Table. Agriculture Related Industry Codes: Any Observation Having Either One of These Codes Was Selected into Our Sample

\begin{tabular}{|c|c|}
\hline A & Agriculture, forestry, animal husbandry and fishery \\
\hline 01 & Agriculture \\
\hline 011 & Grain and other crops \\
\hline 0111 & Grain cultivation \\
\hline 0112 & Potato cultivation \\
\hline 0113 & Oil plantings \\
\hline 0114 & The cultivation of beans \\
\hline 0115 & Cotton cultivation \\
\hline 0116 & Bast Fiber cultivation \\
\hline 0117 & Sugar plantings \\
\hline 0118 & Tobacco cultivation \\
\hline 0119 & Other crops are grown \\
\hline 012 & Vegetables, horticultural crops \\
\hline 0121 & Vegetable cultivation \\
\hline 0122 & Flower planting \\
\hline 0123 & Other horticultural crops \\
\hline 013 & Fruit, nuts, beverages and spice crops \\
\hline 0131 & Fruit, nuts cultivation \\
\hline 0132 & Tea and other beverage crops \\
\hline 0133 & Spice crop cultivation \\
\hline 0140 & Chinese herbal medicine cultivation \\
\hline 02 & forestry \\
\hline 021 & Cultivation and planting of trees \\
\hline 0211 & Breeding and nursery \\
\hline 0212 & afforestation \\
\hline 0213 & Tending and management of trees \\
\hline 022 & Timber and bamboo harvesting \\
\hline 0221 & Timber harvesting \\
\hline 0222 & Bamboo harvesting \\
\hline 0230 & Collection of forest products \\
\hline 03 & Animal husbandry \\
\hline 0310 & Livestock breeding \\
\hline 0320 & Feeding of pigs \\
\hline 0330 & Feeding of poultry \\
\hline 0340 & Hunting and catching animals \\
\hline 0390 & Other animal husbandry \\
\hline 04 & Fisheries \\
\hline 041 & Marine fisheries \\
\hline 0411 & Marine cultivation \\
\hline 0412 & Marine fishing \\
\hline 042 & Inland fisheries \\
\hline 0421 & Inland farming \\
\hline 0422 & Inland fishing \\
\hline 05 & Agriculture, forestry, animal husbandry and fishery services \\
\hline 051 & Agricultural Services \\
\hline 0511 & Irrigation services \\
\hline 0512 & Agricultural products processing services \\
\hline 0519 & Other Agricultural Services \\
\hline 0520 & Forestry services \\
\hline 053 & Livestock services \\
\hline 0531 & Veterinary services \\
\hline 0539 & Other livestock services \\
\hline
\end{tabular}




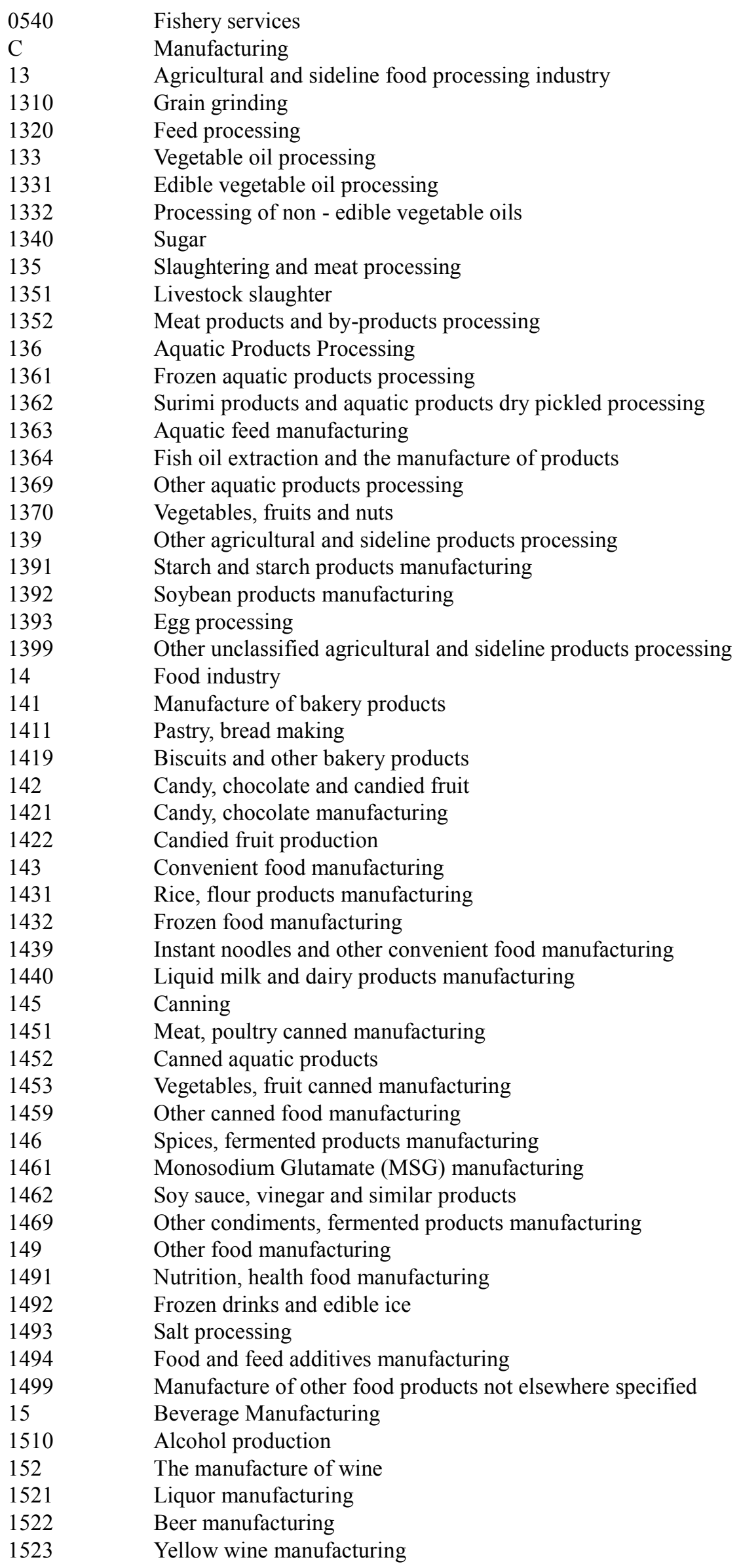


Wine making

Manufacture of other wines

Soft drink manufacturing

Carbonated beverage manufacturing

Bottles (cans) installed drinking water production

Fruit and vegetable juice and fruit and vegetable juice beverage manufacturing

Milk beverage and plant protein beverage

Solid beverage manufacturing

Tea drinks and other soft drinks manufacturing

Refined tea processing

Tobacco Products Industry

Tobacco re-baking

Manufacture of cigarettes

Other tobacco products processing

Wood processing and wood, bamboo, rattan, brown, grass products industry

Sawn timber, wood processing

Sawn timber processing

Wood processing

Wood - based panel manufacturing

Manufacture of plywood

Fiberboard manufacturing

Manufacture of particleboard

Other wood-based panels, wood manufacturing

Wood products manufacturing

Wood and wood components for construction

Wood container manufacturing

Cork products and other wood products manufacturing

Bamboo, rattan, brown, grass products manufacturing

Fertilizer manufacturing

Nitrogen fertilizer manufacturing

Phosphate fertilizer manufacturing

Potash manufacturing

Manufacture of compound fertilizers

Organic fertilizer and microbial fertilizer manufacturing

Manufacture of other fertilizers

Pesticide manufacturing

Chemical pesticide manufacturing

Biochemical pesticides and microbial pesticide manufacturing

Pieces of Chinese medicine processing

Chinese medicine manufacturing

Veterinary drug manufacturing

Biological, biochemical products manufacturing

Manufacture of metal tools for agricultural and garden use

Food, beverages, tobacco and feed production of special equipment manufacturing

Food, beverages, tobacco industry-specific equipment manufacturers

Agricultural and sideline food processing equipment manufacturing

Special equipment for feed production

Agriculture, forestry, animal husbandry, fishing special machinery manufacturing

Manufacture of tractors

Mechanized agriculture and horticultural machinery manufacturing

Forest and wood harvesting machinery manufacturing

Livestock machinery manufacturing

Fishery machinery manufacturing

Agriculture, forestry, animal husbandry and fishery machinery parts manufacturing

Other farming, forestry, animal husbandry and fishery machinery manufacturing and mechanical repair Grain, cotton and other agricultural products storage

Wholesale and retail trade 
Seeds, feed wholesale

Cotton, hemp wholesale

Wholesale livestock

Other agricultural and livestock products wholesale

Food, beverages and tobacco products wholesale

Rice, flour products and edible oil wholesale

Cakes, sweets and sugar wholesale

Fruits, vegetables wholesale

Meat, poultry, eggs and aquatic products wholesale

Salt and condiments wholesale

Beverages and tea wholesale

Wholesale of tobacco products

Other food wholesale

Mineral products, building materials and chemical products wholesale

Fertilizer wholesale

Pesticide wholesale

Agricultural film wholesale

Machinery and equipment

Wholesale of agricultural machinery

Food, beverages and tobacco products specialized retail

Grain and oil retail

Pastry, bread retail

Fruit, vegetable retail

Meat, poultry, eggs and aquatic products retail

Beverages and tea retail

$6526 \quad$ Retail of tobacco products

$6529 \quad$ Other food retail

7312

\section{Appendix 2-Addition Explanation of the OP Method for Calculating TFP}

We use a similar method to Yasar, Raciborski and Poi's work [38] for estimating TFP in this paper, employing the Opreg programming order package which was developed by these authors for the software Stata. The basic concept of this method is as follows.

First, we assume the following production function:

$$
Y_{i t}=F\left(E_{i t}, K_{i t}, a_{i t}, \omega_{i t}\right)(a)
$$

We can derive the following equation based on the Cobb-Douglas technology assumption:

$$
\begin{gathered}
y_{i t}=\beta_{0}+\beta_{e} e_{i t}+\beta_{k} k_{i t}+\beta_{a} a_{i t}+u_{i t}(b) \\
u_{i t}=\omega_{i t}+\sigma_{i t}(c)
\end{gathered}
$$

In equation (b), $y_{i t}$ is $\log$ output for firm i in period t. $e_{i t}$, $k_{i t}$ and $a_{i t}$ are the log values of total employment, fixed capital, and age of the firm i. $\omega_{i t}$ is the productivity shock which is observed by the decision maker in the firm but not by the econometrician and $\sigma_{i t}$ is an unexpected productivity shock which is not observed by both decision maker and the econometrician. This means that $\omega_{i t}$ has an effect on the firm's decision making process and can lead to biased estimation, while $\sigma_{i t}$ does not.

Olley and Pakes [37] define the decision making process as follows:

$$
x_{i t}=\left\{\begin{array}{c}
1 \text { if } \omega_{i t} \geq \underline{\omega}_{i t}\left(k_{i t}, a_{i t}\right) \\
0 \text { otherwise }
\end{array}\right.
$$

Which indicates that firm I would decide to stay in the market $\left(x_{i t}=1\right)$ or exit the market $\left(x_{i t}=0\right)$ if its productivity is greater than or less than a threshold determined by the firm's capital stock and age. Then we can derive the firm's decision to increase future investment $I N_{i t}$ as follows $\left(i n_{i t}\right.$ is the log value of $I N_{i t}$ which is identified by the current assets of the firm $i$ in period $t$ in this paper):

$$
i n_{i t}=I\left(\omega_{i t}, k_{i t}, a_{i t}\right)(e)
$$

We can apply this in the former equations to control for the correlation between the productivity shock error term and inputs.

One more thing has to be emphasized here is that we assume that future productivity is strictly increasing with respect to $\omega_{i t}$, which means that firms with an observed positive productivity shock in period $t$ will invest more in that period while keeping $k_{i t}$ and $a_{i t}$ the same. We can derive the 
inverse function of $\omega_{i t}$ as follows:

$$
\omega_{i t}=I^{-1}\left(i n_{i t}, k_{i t}, a_{i t}\right)=g\left(i n_{i t}, k_{i t}, a_{i t}\right)(f)
$$

Substituting equations $(c)$ and $(f)$ into $(b)$ we have:

$$
\begin{gathered}
y_{i t}=\beta_{e} e_{i t}+\varphi\left(i n_{i t}, k_{i t}, a_{i t}\right)+\sigma_{i t}(e) \\
\varphi\left(i n_{i t}, k_{i t}, a_{i t}\right)=\beta_{0}+\beta_{k} k_{i t}+\beta_{a} a_{i t}+g\left(i n_{i t}, k_{i t}, a_{i t}\right)(g)
\end{gathered}
$$

To obtain the parameter estimate $\hat{\beta}_{k}$, we posit that the probability of survival in period $t$ for firm i depends on the relation between $\omega_{i, t-1}$ and $\underline{\omega}_{i, t-1}$ which can be expressed by the age, capital and investment in period $\mathrm{t}-1$ (a deduction of the Bellman equation in the work of Olley and Pakes (1996)). Yasar, Raciborski and Poi (2008) used a probit model to calculate the predicted probabilities $\hat{P}_{i t}$ with the final equation as follows:

$$
y_{i t}-\hat{\beta}_{e} e_{i t}=\beta_{k} k_{i t}+\beta_{a} a_{i t}+h\left(\hat{\varphi}_{t-1}-\beta_{k} k_{i, t-1}-\beta_{a} a_{i, t-1}, \hat{P}_{i t}\right)+\sigma_{i t}(h)
$$

Moreover, similar to Yasar, Raciborski and Poi' work [38], we assume that $\varphi(\cdot)$ and $h(\cdot)$ approximate a second-order polynomial series. Estimating the parameters using OLS we calculate TFP from the following equation:

$$
T F P^{O P}{ }_{i t}=y_{i t}-\hat{\beta}_{e} e_{i t}-\hat{\beta}_{k} k_{i t}(i)
$$

\section{References}

[1] Helpman E, Melitz M J, Yeaple S R. Export versus FDI with Heterogeneous Firms [J]. The American Economic Review, 2004, 94 (1): 300-316.

[2] Song Z, Storesletten K, Zilibotti F. Growing like china [J]. The American Economic Review, 2011, 101 (1): 196-233.

[3] Cui L, Jiang F. State ownership effect on firms' FDI ownership decisions under institutional pressure: a study of Chinese outward-investing firms [J]. Journal of International Business Studies, 2012, 43 (3): 264-284.

[4] Wei Tian, Miaojie Yu, Firm productivity and outward direct investment: empirical study based on firm level data [J]. China Economic Quarterly, 2012, v11, No. 4402: 383-408.

[5] Feenstra R C. Advanced international trade: theory and evidence [M]. Princeton university press, 2015.

[6] Dunning J H, Rugman A M. The influence of Hymer's dissertation on the theory of foreign direct investment $[\mathrm{J}]$. The American Economic Review, 1985: 228-232.

[7] Dunning J H. International Production and the Multinational Enterprise (RLE International Business) [M]. Routledge, 2012

[8] Krugman P. Increasing returns, monopolistic competition, and international trade [J]. Journal of International Economics, 1979, 9 (4): 469-479.

[9] Vernon R. International Investment and International Trade in the Product Cycle [J]. Quarterly Journal of Economics, 1966, 80 (2): 190-207.

[10] Buckley P J, Cross A R and Tan H. Historic and emergent trends in Chinese outward direct investment. [J]. Management International Review, 2008, 48 (6): 715-748.

[11] Buckley P J, Clegg L J, Cross A R, et al. The determinants of Chinese outward foreign direct investment $[\mathrm{J}]$. Journal of international business studies, 2007, 38 (4): 499-518.

[12] Melitz M J. The impact of trade on intra-industry reallocations and aggregate industry productivity [J]. Econometrica, 2003, 71 (6): 1695-1725.

[13] Girma, S., R. Kneller, and M. Pisu, Exports versus FDI: An
Empirical Test [J]. Review of World Economics, 2005, Vol. 141 (2), 193-218.

[14] Murakami, Y., Are Multinational Enterprises More Productive? A Test of the Selection Hypothesis [J]. Journal of Asian Economics, 2005, Vol. 16 (2), 327-339.

[15] Kimura, F. and K. Kiyota, Exports, FDI, and Productivity: Dynamic Evidence from Japanese Firms [J]. Review of World Economics, 2006, Vol. 142 (4), 695-719.

[16] Castellani, D. and A. Zanfei, Internationalization, Innovation and Productivity: How Do Firms Differ in Italy [J]. The World Economy, 2007, Vol. 30 (1), 156-176.

[17] Yeaple, S. R., Firm Heterogeneity and the Structure of U.S. Multinational Activity [J]. Journal of International Economics, 2009, Vol. 78 (2), 206-215.

[18] Chen, M. X., and M. Moore, Location Decision of Heterogeneous Multinational Firms [J]. Journal of International Economics, 2010, Vol. 80 (2), 188-199.

[19] Arnold, J. M., and K. Hussinger, Exports versus FDI in German Manufacturing: Firm Performance and Participation in International Markets [J]. Review of International Economics, 2010, Vol. 18 (4), 595-606.

[20] Todo, Y., Quantitative Evaluation of Determinants of Export and FDI: Firm-Level Evidence from Japan [J]. The World Economy, 2011, Vol. 34 (3), 355-381.

[21] Hagemejer, J., and M. Kolasa, Internationalization and Economic Performance of Enterprises: Evidence from Polish Firm-Level Data [J]. The World Economy, 2011, Vol. 34 (1), 74-100.

[22] Brainard S L. An empirical assessment of the proximity-concentration tradeoff between multinational sales and trade [R]. National Bureau of Economic Research, 1993.

[23] Markusen J R, Venables A J. Multinational firms and the new trade theory $[\mathrm{J}]$. Journal of international economics, 1998, 46 (2): 183-203.

[24] Markusen J R, Venables A J. The theory of endowment, intra-industry and multi-national trade $[\mathrm{J}]$. Journal of international economics, 2000, 52 (2): 209-234.

[25] Helpman E. A simple theory of international trade with multinational corporations [J]. Journal of political economy, 1984, 92 (3): 451-471.

[26] Perry M K. Vertical integration: determinants and effects [J]. Handbook of industrial organization, 1989, 1: 183-255.

[27] Engel, D., and V. Procher, Export, FDI and Firm Productivity [J]. Applied Economics, 2012, Vol. 44 (15), 1931-1940. 
[28] Tanaka. A., Firm Productivity and the Number of FDI Destinations: Evidence from a Non-Parametric Test [J]. Economics Letters, 2012, Vol. 117 (1), 1-4.

[29] Shepherd, B., Export and FDI Premia among Services Firms in the Developing World [J]. Applied Economics Letters, 2014, Vol. 21 (3), 176-179.

[30] Song L, Yang J, Zhang Y. State-owned Enterprises' Outward Investment and the Structural Reform in China [J]. China \& World Economy, 2011, 19 (4): 38-53.

[31] Knutsen C H, Rygh A, Hveem H. Does state ownership matter? Institutions' effect on foreign direct investment revisited [J]. Business and Politics, 2011, 13 (1): 1-31.

[32] Amighini, A. A,. Rabellotti R, Sanfilippo M. Do Chinese state-owned and private enterprises differ in their internationalization strategies? [J]. China Economic Review, 2013, 27: 312-325.

[33] Ding Y, Zhang H, Zhang J. Private vs state ownership and earnings management: evidence from Chinese listed companies [J]. Corporate Governance: An International Review, 2007, 15 (2): $223-238$.
[34] Dai M, Maitra M, Yu M. Unexceptional exporter performance in China? The role of processing trade [J]. Journal of Development Economics, 2016, 121: 177-189.

[35] Wooldridge J M. On estimating firm-level production functions using proxy variables to control for unobservables [J]. Economics Letters, 2009, 104 (3): 112-114.

[36] Olley G S, Pakes A. The dynamics of productivity in the telecommunications equipment industry [R]. National Bureau of Economic Research, 1992.

[37] Yasar M, Raciborski R, Poi B. Production function estimation in Stata using the Olley and Pakes method [J]. Stata Journal, 2008, 8 (2): 221.

[38] Xiaodong Lu, Yujun Lian. TFP calculating of China industrial enterprises: 1999-2007 [J]. Chinese Economic Quarterly, 2012, 2: $541-558$. 